\title{
Violence on dating relationships among university students
}

\section{La violencia en el noviazgo en estudiantes universitarios}

LEAL-REYES, Rosa Gabriela†, SAMANO-GARCIA, Ma. Hilda, ACOSTA-MONTES DE OCA, Mónica and SOLIS-SEGOVIA, Gabriela

Universidad Autónoma de Tamaulipas, Muldisciplinary Academic Unit of Sciences, Education and Humanities. Mexico.

ID $1^{\text {st }}$ Author: Rosa Gabriela, Leal-Reyes / ORC ID: 0000-0003-1881-2448, CVU CONACYT ID: 491805

ID $1^{\text {st }}$ Coauthor: Ma. Hilda, Samano-Garcia / ORC ID: 0000-0002-9805-4351, CVU CONACYT ID: 618113

ID $2^{\text {nd }}$ Coauthor: Mónica, Acosta-Montes de Oca

ID $3^{\text {rd }}$ Coauthor / Gabriela, Solis-Segovia / ORC ID: 0000-0002-4618-3960, CVU CONACYT ID: 409697

\section{Abstract}

The present research work diagnoses the existence of violence on dating relationships among the students of the Unidad Académica Multidisciplinaria de Ciencias, Educación y Humanidades, of the Universidad Autónoma de Tamaulipas.

Violence, Dating relationships, Students

\section{Resumen}

El presente trabajo de investigación diagnostica la existencia de la violencia en el noviazgo entre el estudiantado de la Unidad Académica Multidisciplinaria de Ciencias, Educación y Humanidades, de la Universidad Autónoma de Tamaulipas.

Violencia, Noviazgo, estudiantes

Citation: LEAL-REYES, Rosa Gabriela, SAMANO-GARCIA, Ma. Hilda, ACOSTA-MONTES DE OCA, Mónica and SOLIS-SEGOVIA, Gabriela. Violence on dating relationships among university students. Journal-Health Education and Welfare. 2020. 4-6:10-26.

$\uparrow$ Researcher contributing as first author. 


\section{Introduction}

While Biology establishes that living beings are born, grow, develop, multiply and die, Sociology, through the Theory of Human Development, establishes that the human species, the living being, goes through several stages in its development: Childhood , Puberty, Adolescence, Youth, Maturity and Serenity, to finally die. In both positions, society has established social institutions that increase the probability of survival of the individual, whether male or female: the Family, the Church, and the School, to name a few. In these institutions, social roles and behavior guidelines are established that must be followed, under penalty of being socially rejected and they begin to be assimilated from the moment of birth. Thus, in the family, one learns to be a boy or a girl, female or male, according to the sex with which one is born, thus, sex is a physiological or biological concept that distinguishes males and females. (Dictionary, Education Sciences 2004).

Learning behavior according to what is expected of one sex or another is known as gender:

Gender, a sociocultural concept, linked to social customs, is a "socially imposed division of the sexes. It is a product of the social relations of sexuality (Lévi Straus: 1994).

In this way, a gender is assigned, a stereotyped behavior to each sex, they are different and almost always, one subjects the other, with what appears, as a result of that teaching, an imbalance of forces. From childhood, the Church reinforces this learning, because it gives the man the responsibility and guardianship of the woman, the father when he is minor or single, and the husband if he is married.

When school age is reached, the school, another social institution is again concerned with reinforcing the predominance of men over women and although it may be thought that upon reaching the age of majority, the person has already learned to defend himself, that the institution family, already taught him what is necessary for the establishment of respectful dating relationships.
"The family is the place where all kinds of successes and failures are rehearsed in an environment of protection and tolerance, firmness and affection. The family limits and contains, it is a liberating organism that is in charge of releasing the mature adolescent who is ready for the formation of another unit. It is a system linked and intercommunicated with other systems; The family goes through a cycle where its functions unfold: to be born, grow up, reproduce and die, functions that can be found within a more or less positive or negative framework, within a health framework or acquire certain characteristics of disease or pathology. " (Corsi: 2001).

However, we find, at the higher education level, everyday situations that indicate that this is not the case. The present research work is born from the observance of the continuous, increasingly continuous occurrence of dating violence in the hallways of the school. Hence the deductive idea of a daily reflection of asking ourselves the question: if this is happening in front of our eyes and there is no blushing or shyness when observed committing violent acts and even when, as part of the teaching staff, intervening avoid violence, what will happen when there is no authority figure, what will happen in other schools, in upper-secondary institutions, in secondary schools, primary schools? Then, after days of the event have passed, we see the couples who experienced public violence, very happy, again, as if nothing had happened. According to Aiquipia, (2015), in the relationship, one becomes emotionally dependent on the affective contact of the couple, reaching the point of idealizing the relationship. The thought also arises as to whether violent public behavior was learned in the family, observing their parents, as established by Asensi (2008).

The World Health Organization, (2000), considers that violence is the intentional use of force or physical power, in fact or as a threat, against oneself, another person, a group or a community, that causes or has very likely to cause fatal injury, psychological harm, developmental disorders or deprivation. 
Thus, it was determined the need to do something to detect the existence of courtship among students of the different educational levels of the city, from the upper secondary level to the higher level. Due to the emergence of the pandemic, the capo's work was interrupted and we only managed to apply the instrument to students from a single school, the Academic Unit of Education Sciences and Humanities (UAMCEH), dependent on the Autonomous University of Tamaulipas (UAT), so we consider the following.

\section{Research questions:}

- In what percentage does dating violence exist among UAMCEH students?

What is the gender that exerts the most violence in dating, among UAMCEH students?

- What type of violence is practiced with the highest frequency in dating among UAMCEH students?

- What is the type of violence exercised by women towards men more frequently, among the students of the UAMCEH?

What is the type of violence that men exert against women with greater frequency, among the students of the UAMCEH?

Objectives:

Determine the percentage of dating violence among UAMCEH students?

- Diagnose which is the gender that exerts the greatest violence in dating, among the students of the UAMCEH?

Analyze what type of violence is exerted in dating among UAMCEH students?

What is the type of violence exercised by women towards men with the greatest frequency, among UAMCEH students?

Identify what is the type of violence that men exert against women with greater frequency, among students of the UAMCEH?

\section{Justification}

The present research work will diagnose the existence of violence in the Multidisciplinary Academic Unit of Sciences, Education and Humanities of the Autonomous University of Tamaulipas, and later it will impact on students in general. It will contribute to the knowledge and subsequent reduction of dating violence among UAMCEH UAT students, which will impact decision-making to improve couple relationships and the possibility of reducing dating violence, transcends married life. This benefit will be obtained by giving lectures on self-esteem, gender roles and stereotypes to the student body. Later, a longitudinal study will be carried out to try to measure the impact of the lectures given.

\section{Theoretical framework}

UAMCEH UAT students have an age ranging from 18 to 23 years, in general, although there are some who exceed 25 , which places them, according to the Theory of Human Development. In this phase of her personal development, the search for a mate is clearly observed in classrooms or in school gardens and in events that are organized openly to the entire student population. Bowlby, in her Theory of Attachment, (1982), affirms that the human being has a pressing need to build binding relationships in order to survive, which are fixed from childhood and are reproduced in their adult relationships.

From the sociocultural perspective, the practices of violence are transmitted generationally. Learning these ways of relating, which harm and cause suffering, are part of the cultural heritage of the communities.

It is generally expected that studying at the university will shield them against unequal relationships and violence, but the reality is that this is not the case. Violent practice has often been seen in dating relationships, and although they arrive almost always of legal age, and it is believed that he already learned, from his home, from his family, to live respectfully in society, not It is thus, then according to Corsi (2001): 
"The family is the place where all kinds of successes and failures are rehearsed in an environment of protection and tolerance, firmness and affection. The family limits and contains, it is a liberating organism that is in charge of releasing the mature adolescent who is ready for the formation of another unit. It is a system linked and intercommunicated with other systems; The family goes through a cycle where its functions unfold: to be born, grow up, reproduce and die, functions that can be found within a more or less positive or negative framework, within a health framework or acquire certain characteristics of disease or pathology. " (Corsi: 2001).

As the human being increases her age, it is argued, that the probability of being a victim of violence decreases, according to Bonomi et al. (2013), they argue that the younger the age, the greater the existence of violence, in this

Violence has different ways of manifesting itself, (Whaley Sánchez: 2003) not only manifests when it leaves physical evidence, but also those acts that affect the emotionality of human beings, affecting their mental health and in some cases, in the total abandonment, product of that omission, aggression or mistreatment.

\section{Types of Violence}

According to Torres Falcón (2001), violence can take different forms, the most common being:

\section{Physical violence}

It refers to all violent actions that cause physical and bodily harm to the victim's body. Physical violence is the most obvious, although sometimes it also produces internal injuries, which are later identified, it has an upward spiral that can start from games and jokes, to cause injuries and even death (Casique and Castro, 2010)

Physical violence includes: pulling, hitting of any kind, wounds, mutilations and can culminate in murder, slapping, hair pulling, shaking, immobilization of the victim, electric shocks, immersing the victim's head for a certain time in water, shaking a bottle with mineral water and release the liquid into the victim's nose.
Physical violence is sometimes more harmful when using firearms or sharp weapons, or any other type of object and sometimes the body itself. There are cases of physical violence by omission, for example, when someone is deprived of food, drink or medicine or when victims are abandoned and even when they are prevented from leaving their home.

Another type of physical violence is sexual violence. It is a type of violence that can take several forms: One, consists of inserting the penis into the victim's body, it can be in the mouth, vagina or anus. Through the use of physical or moral force.

Penetration of the anus or vagina with a part other than the penis is also a violation. It is also considered sexual violence, all the impositions of sexual conduct, even if there is no intercourse.

The "touching" without authorization of the victim, even if there is no penetration. Sexual violence is considered when it is forced to touch the body of the aggressor and to carry out sexual practices, which the victim does not want, (Póo and Vizcarra (2008) Harassment and harassment are also considered as sexual violence, when the integrity of The person Mocking the victim's sexuality is considered a violent act.

In sexual violence, physical violence is mixed, on the one hand, by subduing the body of the victim and psychological violence, by attacking the emotionality of the same, in a word, it consists of harassing or hurting painfully and without authorization to the victim. victim, during sex.

\section{Psychological Violence}

In psychological violence, the end pursued by the aggressor is to humiliate, insult, degrade the victim so that she feels bad, although she does not touch "not a hair". (Batjin: 1996), includes mockery, offense, doubts about the victim's capabilities, insults, yelling, sarcasm, deception, manipulation, contempt, ignorance of the existence of the victim, denial of the rights of the other, lack of respect to the partner, harassment, harassment, death threats, suicide, denial of the feelings of the person who receives the violence. 
This violence does not present physical damage and the victim only presents discomfort, confusion, uncertainty; produces emotional damage to the victim. This type of violence includes: rejection, contempt, ridicule and the insult that they apply, which translates into a decrease in their self-esteem and sometimes somatizes, manifesting in insomnia, physical alterations, skin diseases, ulcers, migraines, headaches, migraines, muscle aches, as a physiological response whose origin is in the emotional sphere. Wolfe and others point out that emotional violence is provoked with disqualifying insults, labels, and in general, the use of language that causes damage to selfesteem, identity and self-concept. In emotional violence, control is very often exercised by one over the other, the aggressor, the victim, it can be exercised by both sexes. (Pazos 2004)

The means that are most used in this type of violence are scathing, lies. Ridicule, sarcasms related to the physical appearance of the victim, silence, offenses, hurtful jokes, isolation and threats to murder the victim, commit suicide or exercise other types of violence, for example physical or sexual.

\section{Economic or Financial Violence}

It is the involuntary alienation or seizure, material control, dispossession or theft of the victim's personal or real property.

Economic or financial violence is carried out when one of the parties of the couple seizes the effective disposition of the goods and values that belong to the other person. Economic violence is also suffered when the aggressor uses his own resources to commit and subdue the victim. Person, representing a sentimental value to the victim.

The most used forms of violence are theft, fraud, damage to the victim's property or the destruction of the victim's property.

Economic violence is also practiced when the victim is deprived of the means to satisfy the victim's basic needs, such as food, clothing, housing, education and health.
Forms of Violence:

\section{As Aggression}

This form occurs in egalitarian relationships, that is, where there is no victim or executioner. The interacting relationships have symmetric relationships. The behavior patterns of the individuals who interact tend to manifest themselves in a reciprocal way.

Violence-aggression can manifest itself as an exchange of blows, in a context of an equal relationship. The participants, force, status and power, unleash an aggression and this is mutual, reciprocal and public. According to Celis (2015), dating relationships are expressed when he or she expresses their dominant and aggressive behavior towards the other person

Relationships can continue because after the aggression in a symmetrical relationship, a "complementary pause" can follow, where the sender of the violence asks for forgiveness and exchanges the position of equality to that of inferiority to attend to the one who suffered the violence. This stage occurs in two phases:

First: Appearance of the feeling of guilt that makes us think about the unnecessary use of violence. This phase can become the reason for the separation and lead to the end of this relationship.

Second: The need to repair the damage, is the behavior that tries to forget, downplay the fact, excuse the violent act, which serves to maintain the "harmony and solidarity of a good family."

Sometimes this extra pause can be used to ask for help outside the family circle, usually from a behavioral professional.

In violence-aggression, identity and self-esteem are recognized and the existence of the other is accepted. Both are concerned with resolving the conflicts that trigger the violent process and resolving the differences to continue the relationship. 


\section{As Punishment}

This form of violence occurs in an unequal relationship, where there is a complementary relationship, where each of the participants accepts the role (E-R) that they "should" play. There is a difference in the hierarchy of power and both accept it.

Individuals will act in a complementary or symmetrical way, depending on the social group in which they are interacting. Thus, a person can be inferior in one relationship, superior in another, and equal in one more.

Violence-punishment is observed in an unequal, asymmetric relationship, where sanctions, torture and lack of care from the "Issuer" to the "Receiver" are accepted by both parties because they share the belief that one has a "right" to inflict punishment and the other, the "Receiver", has the "obligation" to receive it, silently and in private.

Violence-punishment, (Beck: 1999) is unilateral and intimate; the life of the "Issuer" is superior to that of the "Receiver", who must submit to punishment even against his will.

According to Beck, the Sender, the Receiver, who is the object of the punishment, is guilty because he has committed a fault. In turn, the Receiver believes that he must conform to the life that is imposed on him, and Judeo-Christian thought contributes to spreading that belief, because God so arranged it before his own birth. The beatings and abuse present an identity disorder and it is justified because the Receiver generates a feeling of guilt towards the Sender, who is rigid, lacking in empathy, inconsiderate and indifferent to the other.

The Issuer presents rigid, inflexible ideas and wants to rectify everything that is different from their ideas, wants to attack the other, even to "domesticate" him so that do "what you must do", according to his idea of reality and the world. Regardless of the interaction, both individuals, both Sender and Receiver, have very low self-esteem.

Violence is always organized under a series of sequences that the couple organizes, encodes and interprets, with the intervention of the following elements.
These aspects have a strong emotional charge that depends on the individual history of the participants and their interaction that it is necessary to clarify the terms involved in a social interaction that leads to violence (Botinelli: 2000):

Consensus: Both individuals organize their life together, setting limits and boundaries that should not exceed either of the two; generally one or some things are limited and all the others are allowed, which is incongruous.

Space: These are the individual and collective limits and territory where the violence will take place and can be private or public; individual or collective.

Time: It is the chronology with which the events that trigger the violence occur, establishing rites and sequences.

- Reasons: They are the "causes" that justify the unleashing of the violent process.

However, a small change in space, time, can modify the acceptance of the implicit consensus that can lose its rigidity. At this time, the actors of the conflict can break the courtship and withdraw from the relationship, that is, they can opt for non-violence or, where appropriate, the breakdown of the courtship.

\section{Methodology}

The type of study carried out is exploratory, descriptive and correlational. The study population was made up of students enrolled in the UAMCEH UAT, during the period 2021. The hypotheses derived from the observation are:

$\mathrm{H} 1$ : Age determines violence in dating relationships among students at UAMCEH UAT.

$\mathrm{H} 2$ : Gender determines the violence that is practiced in dating between students of the UAMCEH UAT

For the study of H1 and H2, Descriptive Statistics was used. In this research, a CrossSectional Design was carried out. 
Research dimensions:

The UAMCEH UAT enrolled 749 students during the January-June 2020 school period. The sample studied amounted to 50 percent of the student population enrolled during the 2020 school period 1 .

The technique used was the survey and the instrument was a questionnaire that was applied to the students of the UAMCEH UAT.

The research space was the Multidisciplinary Academic Unit of Sciences, Education and Humanities, during the period January to June of the year 2020.

An instrument was applied to detect whether or not there is violence among the students of the UAMCEH UAT, divided into two sections, on the one hand, to find out their social context and in a second part, to determine the types of existing violence, they were questions closed response.

The Descriptive Statistics was used to analyze the data collected to translate them into bar graphs, the Office packages were used: Word and Excel.

\section{Results}

\section{Gender}

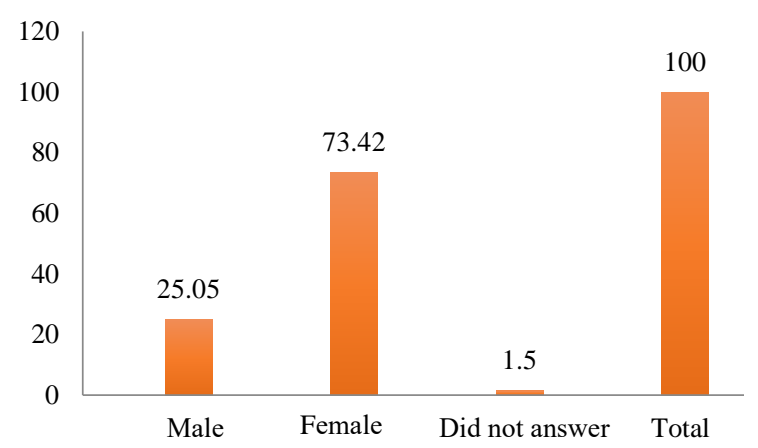

Graphic 1 Gender

Source: Own elaboration

We worked with 459 students, of which $73.42 \%$ belonged to the female gender and $25.05 \%$, to the male gender, while the rest did not answer what gender they belonged to.

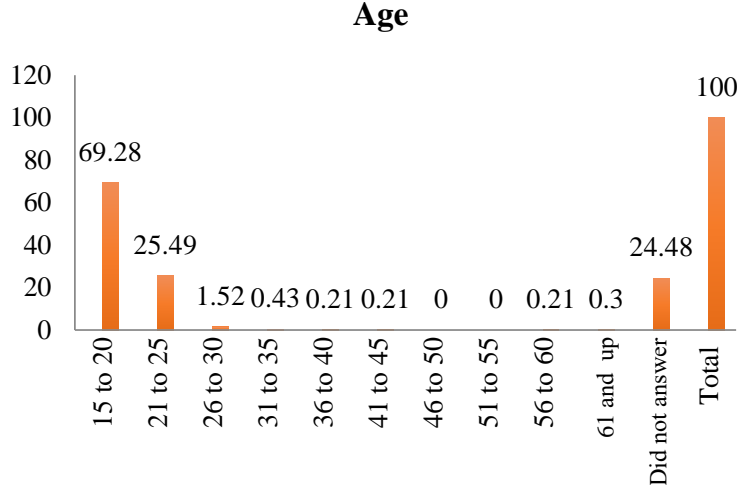

Graphic 2 Age

Source: Own elaboration

$69.28 \%$ of the students surveyed are under 20 years old, $25.49 \%$ are between 21 and 25 years old, while 24.48 , did not answer this question.

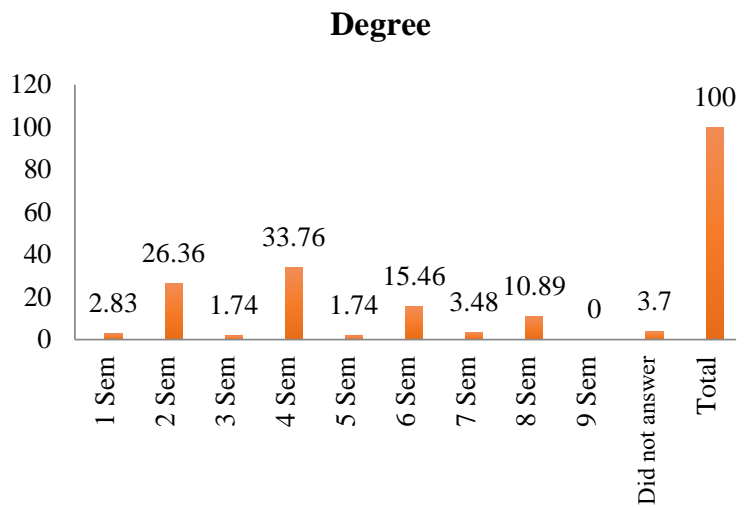

Graphic 3 Degree

Source: Own elaboration

Regarding the Bachelor of Studies, there are students of all grades, but the Second and Fourth Semester stands out, with 26.36 and $33.76 \%$ respectively. Here it is worth mentioning that the upper semesters are made up of very few students, there are groups made up of only 5 students.

\section{Civil status}

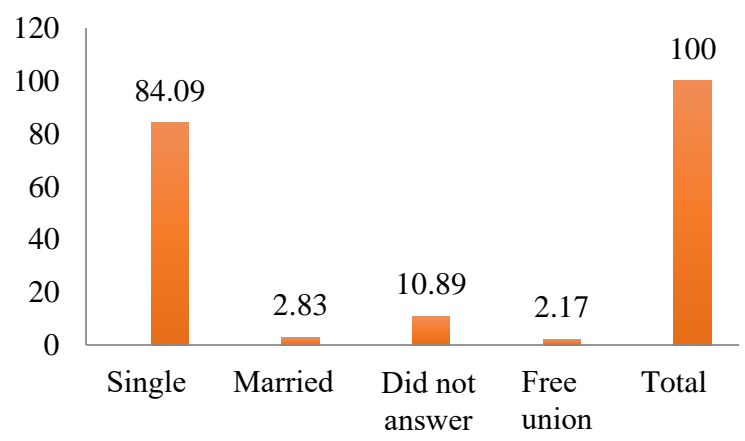

Graphic 4 Civil status

Source: Own elaboration 
When asked about their Marital Status, $84.09 \%$ are Single, while only $2.83 \%$ are already Married. There is $2.17 \%$ who live in Unión Libre, while $10.89 \%$ did not answer.

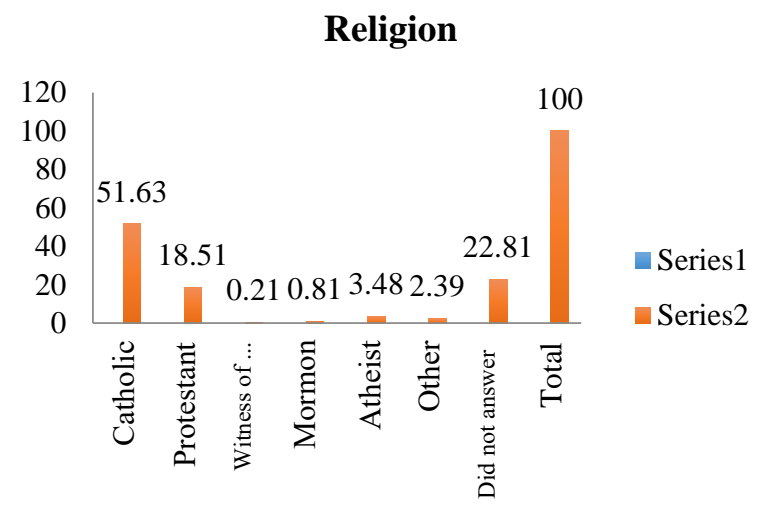

Graphic 5 Religion

Source: self made

Regarding the Religion to which they belong, just over half belong to the Catholic Religion, (51.63\%), 18.51\%. to the Protestant Religion, the remaining responses had percentages lower than $1 \%$. 22.01\% did not answer this question.

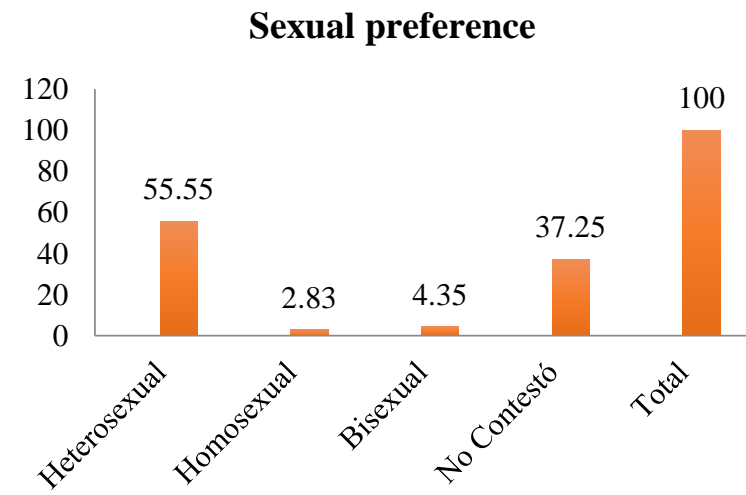

Graphic 6 Sexual preference

Source: Own elaboration

They were asked the Sexual Preference with which they identify, finding that $55.55 \%$ are Heterosexual, $2.83 \%$ said they are Homosexual and $4.35 \%$ are Bisexual. $37.25 \%$ did not respond.

\section{Mother's age}

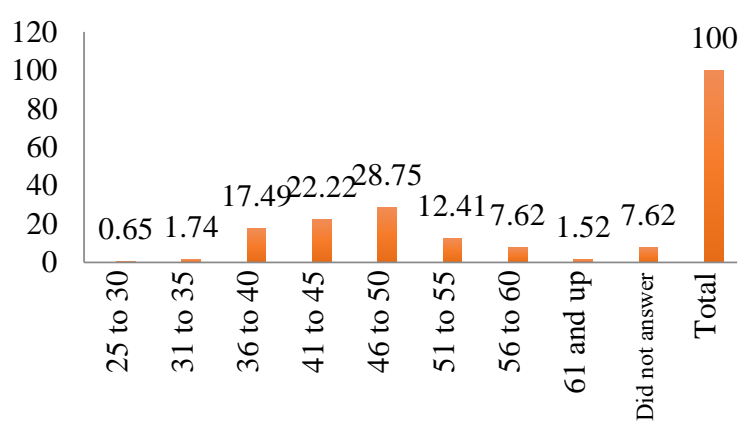

Graphic 7 Mother's age

Source: Own elaboration

The Age of the Mother is highly variable, from 25 to 30 years $(65 \%)$, which may indicate that they are the children of a very young mother (mothers from 13 years of age) and $1.74 \%$ of mothers aged 31 to 35 were observed years of age, perhaps they were mothers at 17 , but the fact that the children are studying may indicate that they received support from their grandparents or that they are hard-working and intelligent or that they have a father much older than the Mother, or that both or at least one of the two has mature and responsible thinking. The highest frequency is found in the age of 46 to 50 years $(28.75 \%)$, we find that from 41 to 45 years there is a $22.22 \%$, from 51 to $55(12.41 \%), 7.62 \%$ with an age of (56 to 60$)$. A very small percentage $(1.52 \%)$ said that their mother is older than 61 , while the rest, $7.62 \%$ did not respond.

\section{Father's age}

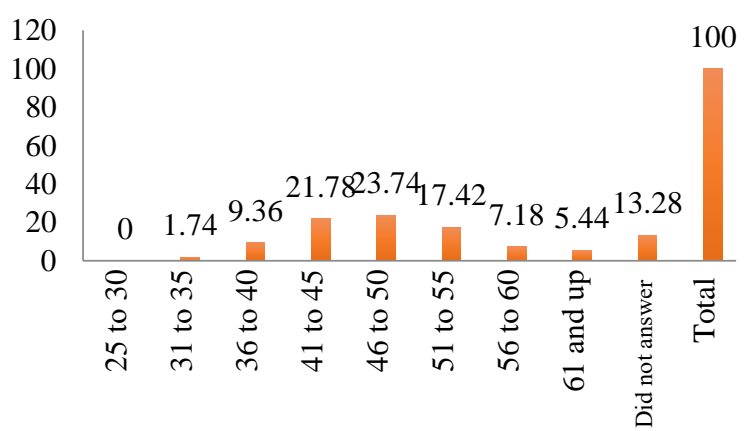

Graphic 8 Father's age Source: Own elaboration 
When asked about the Father's Age, we find that fathers are older than mothers, we do not find under 30 years of age. This is understood by the stereotypical tradition that in a couple, the man must be older than the woman and when it comes to the case that in the couple, the woman is older than the man, that, socially, is reprehensible. And very little percentage of parents $(1.74 \%)$ from 31 to 35 years old, the highest frequency in age, was located in parents from 46 to 50, with $23.74 \%$, followed by $21.78 \%$ of parents aged between 41 to 45 years, 17.42 , with ages between 51 to 55 years, $9.36 \%$, with age between 36 to 40 years. There is $7.18 \%$ of parents aged between 56 to 60 years. It was also noted that there are $5.44 \%$ of parents who are older than 61 years. While a 13.28, did not respond.

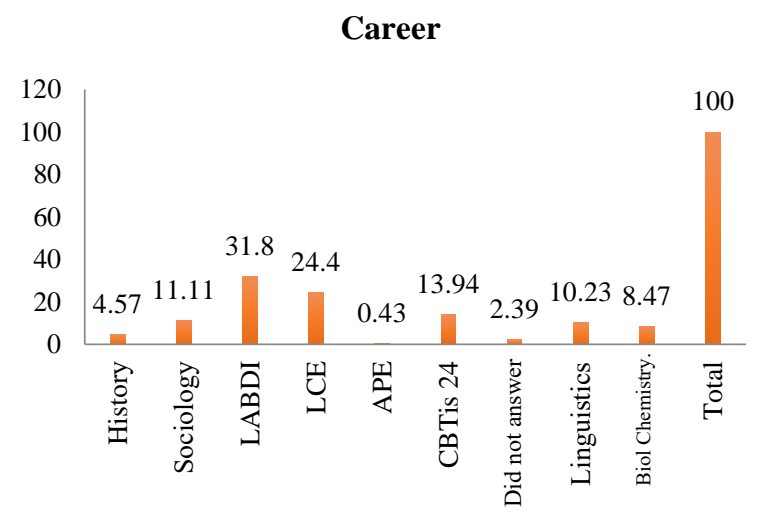

Graphic 9 Career

Source: Own elaboration

Regarding the careers that the surveyed students pursue, those offered by the UAMCEH UAT: Bachelor of History and Management of Cultural Heritage, Bachelor of Sociology, Bachelor of Applied Linguistics, Bachelor of Education Sciences and Bachelor of Attention to Development and Well-being Childish.

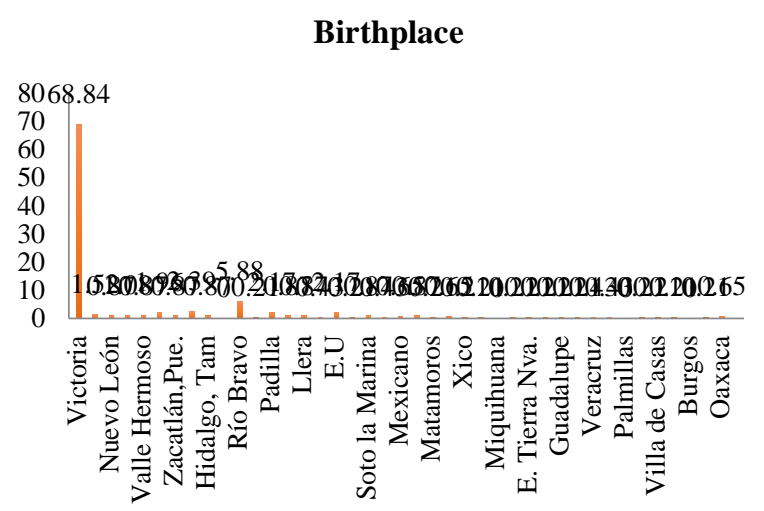

Graphic 10 Birthplace

Source: Own elaboration
Regarding the place of origin, it is very varied, since our students come from various states of the Mexican Republic: Puebla, Nuevo León, Veracruz, Oaxaca, but almost $70 \%$ belong to the state of Tamaulipas. It should be mentioned that we have students from the United States of America, especially those who were returned to our country because their parents lived illegally in the United States and enrolled in the Linguistics Career, because although they can communicate orally in English, they cannot write with established grammar rules.

\section{Are you a regular student?}

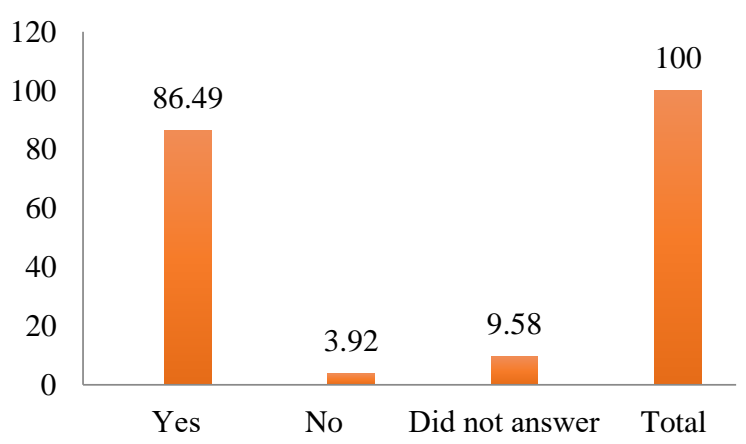

Graphic 11 Are you a regular student? Source: self made

Regarding the question about whether the respondents are Regular Students (this must be understood, as students who do not owe subjects), 86.49 said they are Regular Students, while $3.92 \%$ are not.

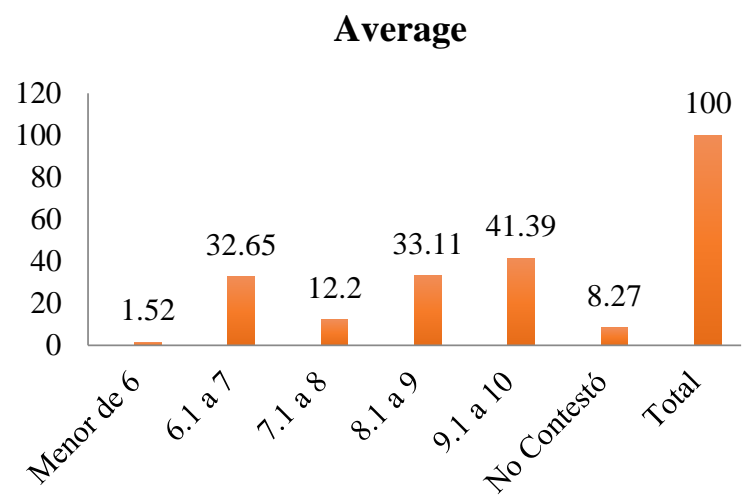

Graphic 12 Average

Source: Own Elaboration

When asked about their average, $41.39 \%$ said they have an average of 9.2 to $10.33 .11 \%$ said they had an average of 8.1 to $9.12 .2 \%$ said they had 7.1 to $8 \%$, while 32.65 had an average of 6.1 to 7 . A percentage of 1.52 said they had an average of less than 6 and $8.27 \%$ did not respond. 
Do you live with your partner?

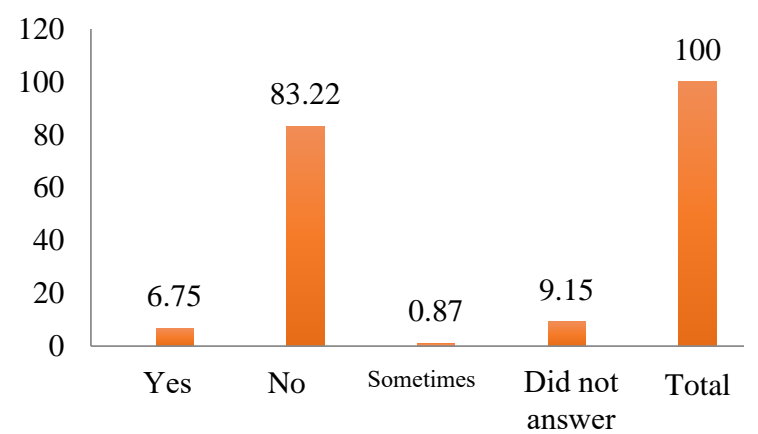

Graphic 13 Do you live with your partner?

Source: Own elaboration

Regarding the causal variables of violence, we have that when asked if they live with their partner, $83.22 \%$ answered No, while $6.75 \%$ If they live with their partner, $0.87 \%$ said that Sometimes, while $9.15 \%$ preferred not to answer.

\section{Do you feel that your partner controls you for love?}

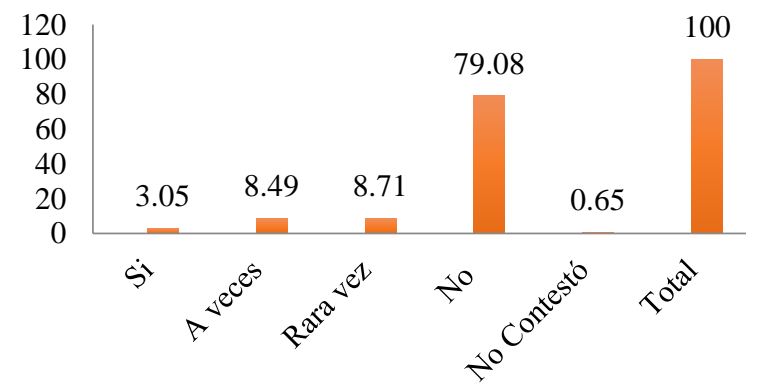

Graphic 14 Do you feel that your partner controls you for love?

Source: Own elaboration

When asked if their partner controls them for love, $79.08 \%$ answer that they do not feel that they are controlled for love, $8.71 \%$ say that they rarely feel that they are controlled for love, $8.49 \%$ say that Sometimes they feel that they control him for love, but there is 3.05 percent who say they feel that they control him for love. $0.65 \%$ did not respond.

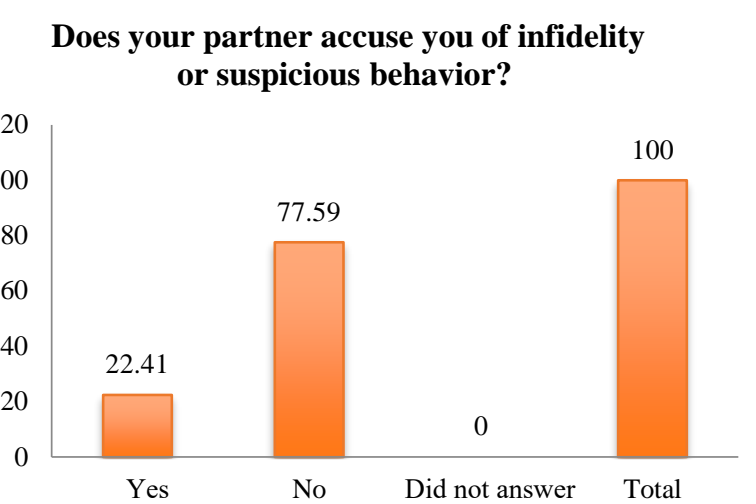

Graphic 15 Does your partner accuse you of infidelity or suspicious behavior?

Source: Own elaboration

When asking the student if his partner accuses him of infidelity or suspicious behavior, 77.77 say that they do not accuse him, $9.15 \%$ say that Rarely do they feel that they are accused of suspicion or infidelity, $7.18 \%$ say that sometimes They accuse you of infidelity or suspicious behavior, but there is $5.88 \%$ that if they accuse you of infidelity or suspicious behavior.

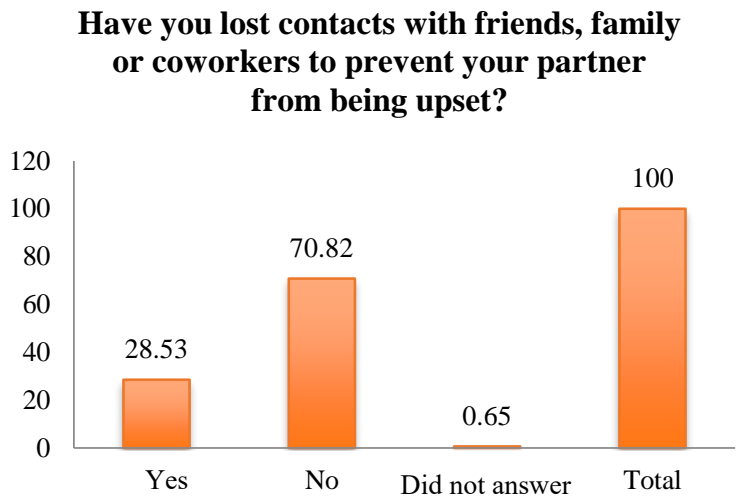

Graphic 16 Have you lost contacts with friends, family or coworkers to prevent your partner from being upset? Source: Own elaboration

When students are asked if they have lost contact with friends, family or colleagues from school or work to prevent their partner from being upset, $71.24 \%$ say No, but there is $9.15 \%$ that If they have lost contact with someone, $7.18 \%$ said that Sometimes they lost contact, $12.2 \%$ said that they rarely lost contact with a friend, family member or work colleague. $0.65 \%$ did not respond. 
Does your partner criticize you, humiliate you in public or private or have a negative opinion about your appearance?

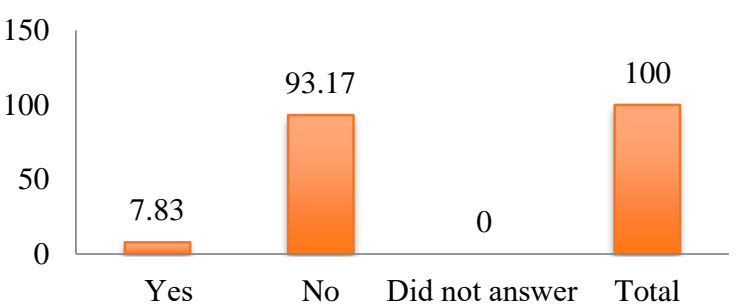

Graphic 17 Does your partner criticize you, humiliate you in public or private or have a negative opinion about your appearance?

Source: Own elaboration

When questioning whether their partner humiliates them in public or thinks negatively about their appearance, 91.93 of those surveyed answered No, while $1.3 \%$ said Yes, $2.83 \%$ said that Sometimes it happens to them, while $3.7 \%$ said that Rarely did that happen to them.

\section{Does your partner have sudden mood swings or behave differently in public, like someone else?}

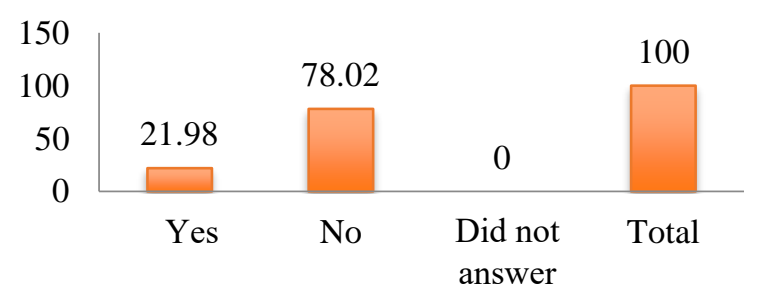

Graphic 18 Does your partner have sudden mood swings or behave differently in public, like someone else? Source: Own elaboration

When addressing the question of whether their partner has sudden mood swings or behaves differently in public, as if they were someone else, $5.22 \%$ said that If those sudden mood swings happened, $7.18 \%$ said that Sometimes it happened to them witnessing this different behavior, 9.58 said that this rarely happened to them, while $77.99 \%$ answered that this situation had not happened to them.
Your partner is in permanent tension and whatever you do, does he get irritated and blame you for his changes?

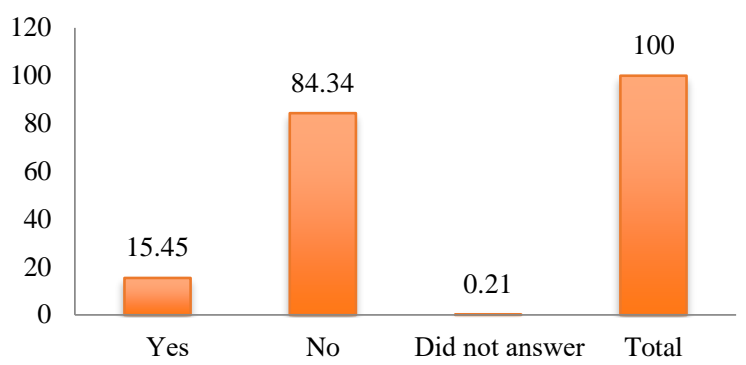

Graphic 19 Your partner is in permanent tension and whatever you do, does he get irritated and blame you for his changes?

Source: Own elaboration

The students responded as follows when asked about whether their partner is in permanent tension, if he is irritated and blames him for his changes: $3.48 \%$ answered that if they feel that irritation and mood changes in their partner. $5.22 \%$ said that Sometimes it happened to them. $6.75 \%$ affirmed that it rarely happened to them, while $84.31 \%$ assured that they did not feel that irritation or mood changes.

Has your partner hit you with his hands, pulled you or thrown objects at you when he is angry or when you argue?

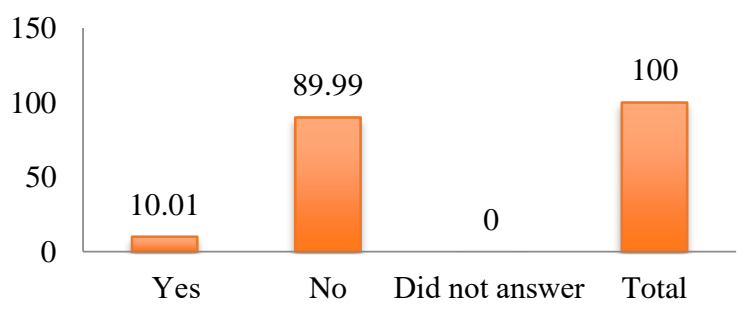

Graphic 20 Has your partner hit you with his hands, pulled you or thrown objects at you when he is angry or when you argue?

Source: Own elaboration

Students were questioned about whether their partner has physically assaulted, pulled or thrown objects when they argue. 3.7\% affirmed that they have suffered it. $1.3 \%$ said that Sometimes they have suffered it. $5.01 \%$ affirm that they have rarely suffered them, there is $89.99 \%$ that affirm that they have not suffered them. 
Has your partner threatened to kill you or someone in your family with an object or weapon?

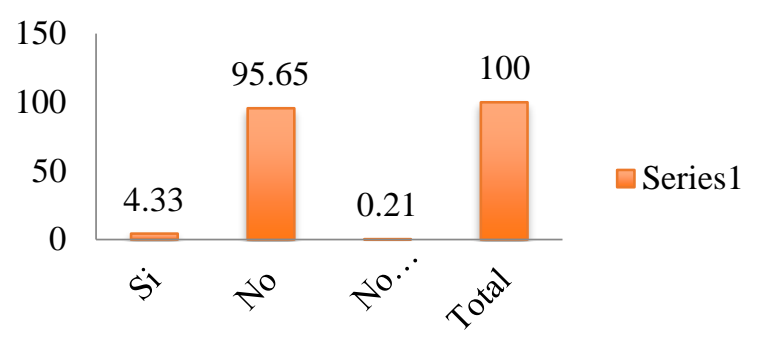

Graphic 21 Has your partner threatened to kill you or someone in your family with an object or weapon? Source: Own elaboration

In the question about whether their partner has threatened them with an object or weapon, or to kill themselves, or kill their partner or someone in the family, $1.08 \%$ said that they have threatened. $1.3 \%$ assured that Sometimes they have been threatened. $1.74 \%$ said that they were rarely threatened, while $93.02 \%$ said that they were not threatened.

Do you give in to your partner's sexual requests or has he forced you to have sex, threatening that if you don't give in, he will go with someone else?

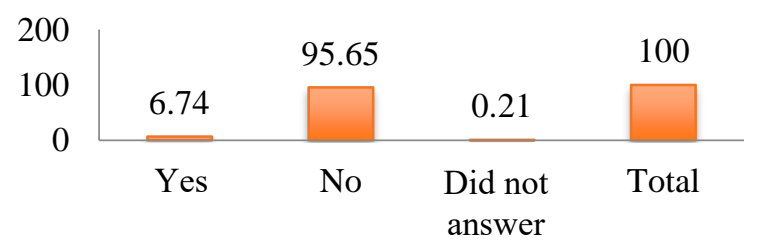

Graphic 22 Do you give in to your partner's sexual requests or has he forced you to have sex, threatening that if you don't give in, he will go with someone else? Source: self made

In the question asked of the students surveyed, he refers to whether he feels that he gives in to sexual requests with his partner, or if he has forced him to have relations, arguing that if he does not agree, he will go with another (a), $2.39 \%$ said they had given in to sexual relations because they received threats from their boyfriend or partner that if they do not agree, they will leave it for another person. $1.74 \%$ argue that at times they have been forced or have agreed under the threat that their partner will leave with another. $2.71 \%$ have agreed to this requirement, rarely, 93.02\%, assure that they have not received this threat.

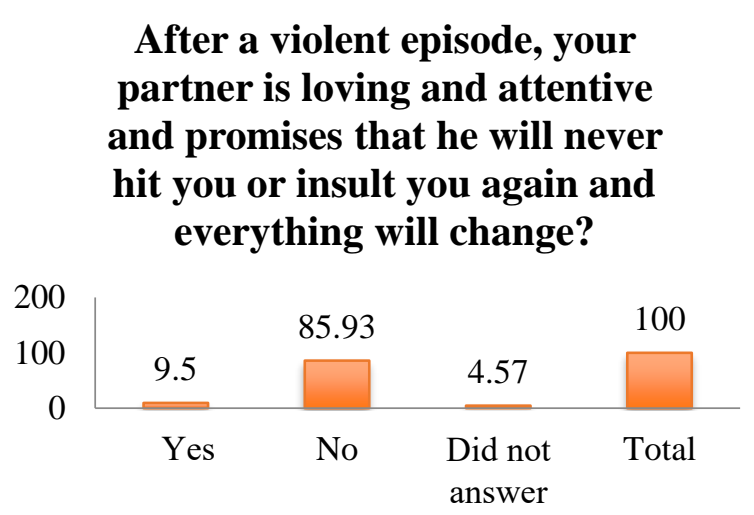

Graphic 23 After a violent episode, your partner is loving and attentive and promises that he will never hit you or insult you again and everything will change? Source: Own elaboration

When the respondent is asked if after a violent episode, his partner is loving and attentive, gives him things and promises that he will never hit or insult him again and that everything will change. $0.43 \%$ said that if they suffered that experience. $4.57 \%$ said they suffer it Sometimes. 5.04\% answered that it rarely happens to them, while $86.49 \%$ said that they have not suffered it. There is a $4.57 \%$ who preferred not to answer.

\section{Have you sought medical, psychological or legal help for injuries that your partner has caused you?}

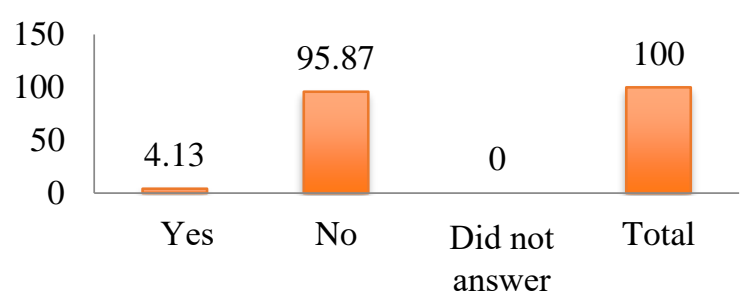

Graphic 24 Have you sought medical, psychological or legal help for injuries that your partner has caused you? Source: Own elaboration

When questioning the respondents if they have sought or received help for injuries that their partner has caused them, such as first aid, medical, psychological or legal help, $1.74 \%$ answered that If they have received help, $1.96 \%$ said that Sometimes they have sought help. $0.43 \%$ stated that help has seldom happened, while $96.73 \%$ said they had not requested help. 


\section{Is your partner violent or fights with other people?}

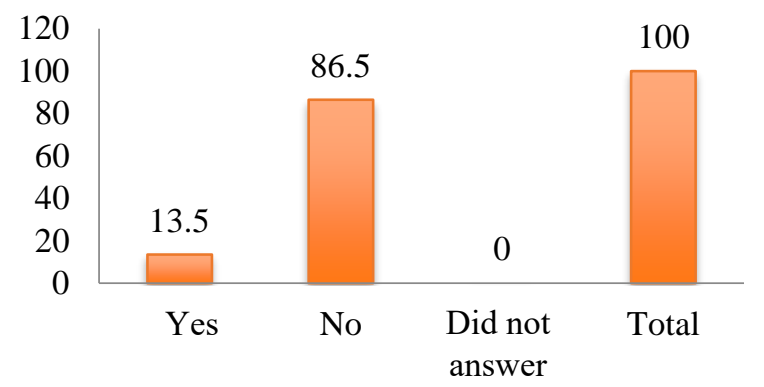

Graphic 25 Is your partner violent or fights with other people?

Source: Own elaboration

When asked if their partner is violent, or if they fight with other people, $1.74 \%$ answered that their partner is violent and has been hitting with other people. $1.96 \%$ said that Sometimes it happened and $9.8 \%$ said that this violent event rarely happened, $86.49 \%$ said that they have not witnessed violent scenes in their partner.

\section{Does your partner control the} way you dress?



Graphic 26 Does your partner control the way you dress? Source: self made

The respondents were asked if their partner controls the way they dress, $1.74 \%$ answered that their partner controls the way they dress. A 3.7 affirms that Sometimes, and an $8.27 \%$ that this happens Rarely. $86.05 \%$ said that their partner does not control the way they dress.

\section{Does your partner decide which people you talk to and who you don't?}

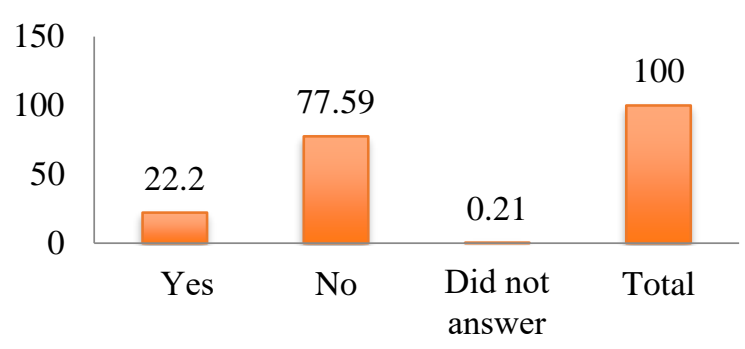

Graphic 27 Does your partner decide which people you talk to and who you don't?

Source: Own elaboration

When students are asked if their partner decides which people he talks to and who he does not talk to, $4.57 \%$ answered Yes. $4.35 \%$ affirm that this happens to them Sometimes. $13.28 \%$ said that Rarely did that happen to them. $77.55 \%$ said that it does not happen. $0.21 \%$ did not answer.

\section{Your partner controls the way you groom yourself, cut your hair, make up, talk, smile?}

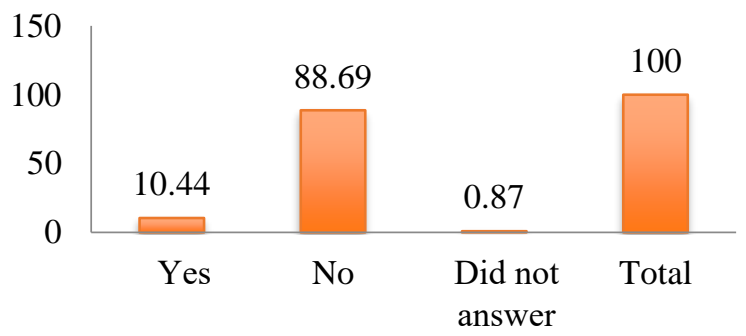

Graphic 28 Your partner controls the way you groom yourself, cut your hair, make up, talk, smile?

Source: self made

When questioning students about whether their partner controls the way they groom themselves, cut their hair, make up or smile, $1.08 \%$ said that their partner does control that aspect. $2.39 \%$ affirm that this happens Sometimes. $6.97 \%$ said that it rarely happened to them. While $88.67 \%$ stated that their partner did not control their way of grooming. 
Does your partner check your personal belongings like cell phone, WhatsApp, Facebook, email, handbag or your wallet?

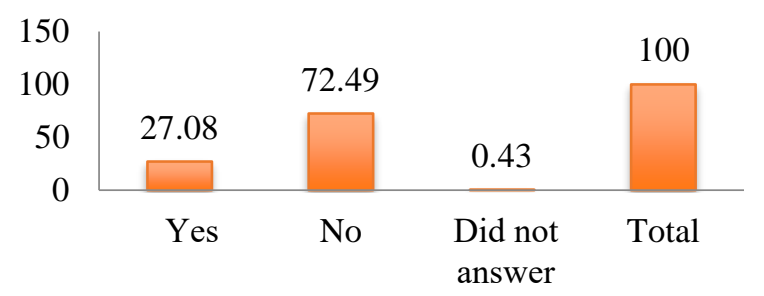

Graphic 29 Does your partner check your personal belongings like cell phone, WhatsApp, Facebook, email, handbag or your wallet?

Source: Own elaboration

When asked if their partner checks their personal belongings such as cell phone, WhatsApp, Facebook, Email, handbag, wallet, $4.79 \%$ of those surveyed said that if their partner checks their belongings. $5.66 \%$ responded that this happens Sometimes. $12.63 \%$ affirmed that it happens Rarely and $76.47 \%$ affirmed that it does not happen. $0.43 \%$ did not respond.

Your partner, after a violent lapse, blackmails you, saying: I am leaving home, will I take my life or will I take drugs?

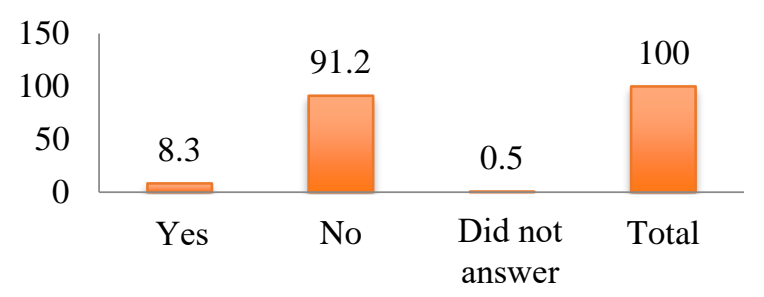

Graphic 30 Your partner, after a violent lapse, blackmails you, saying: I am leaving home, will I take my life or will I take drugs?

Source: Own elaboration

When questioning the respondents about whether their partner has emotionally blackmailed them with: I am going to leave home, I am going to kill myself, I am going to take drugs, after a violent lapse, $3 \%$ said that If they have been blackmailed from that way. $1.8 \%$ assure that this happens to them Sometimes, to $3.5 \%$ it happens Rarely, while to $91.7 \%$ it has not happened. There was a $0.5 \%$ who did not answer.

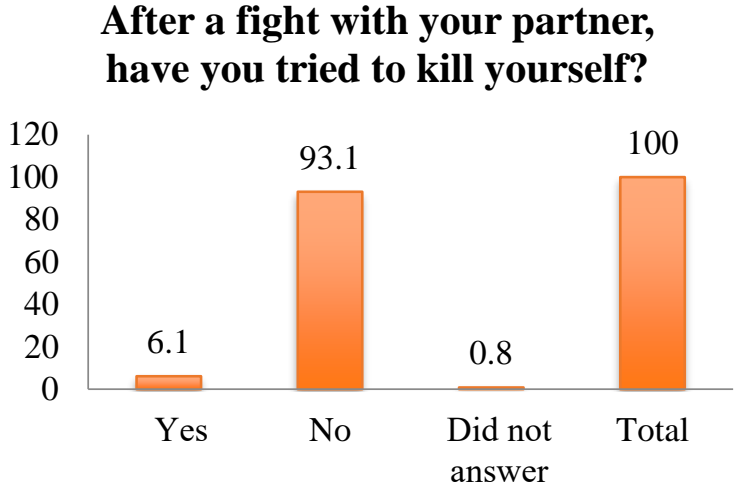

Graphic 31 After a fight with your partner, have you tried to kill yourself?

Source: Own elaboration

In the item that asks whether, after a fight with their boyfriend or partner, they have tried to kill themselves, $2.3 \%$ said that they said that it has happened to them. $1 \%$ said that this happens to them Sometimes and $2.8 \%$ say that it has happened Rarely. 93.2\% assured that it has not happened to them.

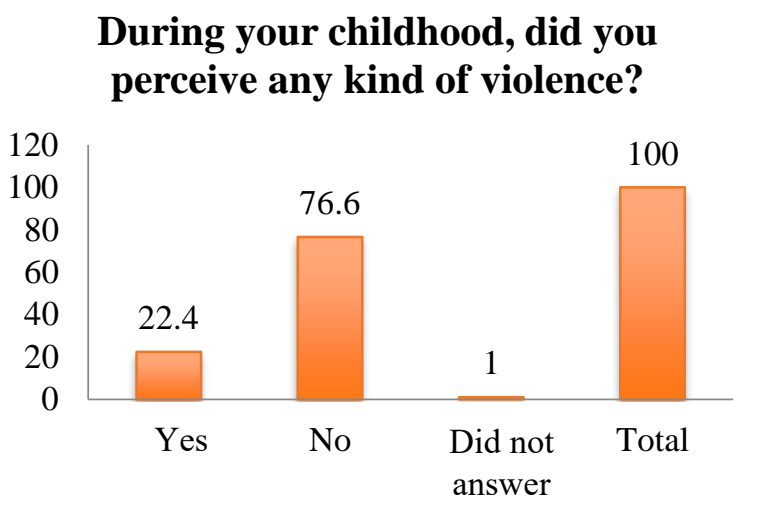

Graphic 32 During your childhood, did you perceive any kind of violence?

Source: Own elaboration

In the question that the student body is asked about whether during their childhood they perceived any type of violence, bad words, 9.3\% answered that If they perceived violence, $4.3 \%$ answered that Sometimes, $8.8 \%$ said that they Rarely perceived violence, while $76.6 \%$ said they had not perceived violence in their childhood. 
Are your partner's lapses of violence caused by alcohol or some other toxic substance?

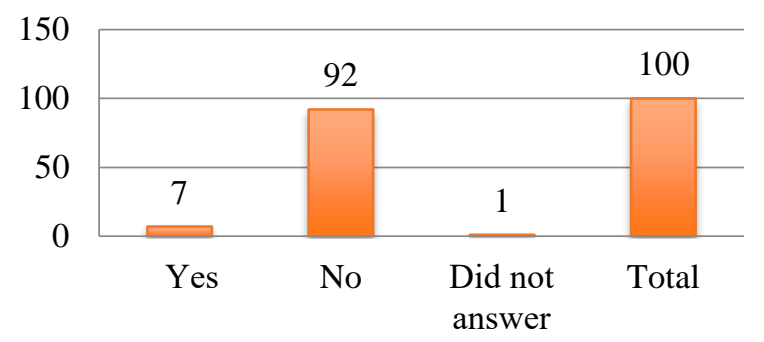

Graphic 33 Are your partner's lapses of violence caused by alcohol or some other toxic substance?

Source: Own elaboration

When asked if their partner's periods of violence are caused by the effects of alcohol or a toxic substance, $3 \%$ answered Yes. $0.5 \%$ of the students answered that Sometimes violent lapses were the result of alcohol or drugs and $3.5 \%$ answered that Violent lapses were rarely the result of alcohol or drugs, while 93\% said that lapses of violence of your partner, They are not the product of the effects of alcohol or toxic substances.

\section{Conclusions}

Violence exists in dating among students of the UAMCEH UAT, in different percentages, according to the type and manifestation.

$20.25 \%$ of the students feel that their partner controls them for love, but a large percentage does not experience it. In a word, a fifth of the student body perceives that they are being controlled. $23.1 \%$ of the male gender, if they control it, and $76 \%$ of the female gender.

Among the students who have been accused of infidelity or suspicious attitude, we found that $22 \%$ of those surveyed have suffered this type of violence, at least once in their dating relationship, contrasting with the almost 80 percent who did not has suffered. $36.4 \%$ of the male gender are accused of infidelity and $63.6 \%$ of the female gender. When analyzing the data and adding the students who have lost contact with someone at least once, we find that almost $30 \%$ of the student body has suffered this type of violence, contrasted with the majority statement of Not having suffered this violence. $33.3 \%$ of the male gender have lost contact with someone, while $66.7 \%$ of the female gender have lost contact.
When the totals of the students who have received humiliation or negative opinions from their partner are added, we find that $7.83 \%$ have suffered it, while $93.17 \%$ affirm that they have not experienced this violence. $33.3 \%$ of the male gender and $66.7 \%$ of the female.

When analyzing and adding how much percentage of the surveyed students have perceived sudden changes in their boyfriend or partner, we find that at least a fifth of the student body has suffered this type of violence, contrasted with less than $80 \%$ who affirm that they have not. suffered. The gender that has the highest percentage of perception of mood changes, in its partner, is the female, with 55\%

When adding the frequencies of the students who at least once have experienced tension in their boyfriend or partner, we find $15.45 \%$, while there was $84.34 \%$ of students who claimed not to have suffered this type of violence. $53.3 \%$ of women have perceived tension in their partner, while men, $46.7 \%$.

$0.01 \%$ of the surveyed population has been physically assaulted by their boyfriend or partner, at least once during their courtship. $57.1 \%$ of men claimed to have received blows from their partner, while women have received them in $42.9 \%$

$4.33 \%$ of all students have suffered death threats, or someone in their family, from their boyfriend or partner. Of this percentage, $72.8 \%$ belong to the female gender and 25.9 , to the male.

$6.74 \%$ of the total student body has been forced to have sexual relations, under threat of being abandoned if they do not give in. Of this percentage, $66.7 \%$ belong to the female gender and $33.3 \%$, to the male gender.

$.47 \%$ of the students have experienced a violent episode with their partner and then the aggressor is affectionate and promises not to physically or verbally attack him again. Of the total number of couples who participate in this type of violence, $61.1 \%$ are men, while $38.9 \%$ are women. 
The total frequencies of students who have seen that their partner or boyfriend is violent or fights with other people, rises to $13.5 \%$, while those who have not seen this violence is $86.5 \%$. Of the total, $75 \%$ are women who have witnessed this violence, while the remaining $25 \%$ are women.

$4.3 \%$ of the total students surveyed have sought medical, psychological or legal help for injuries received by their partner. Of the total number of students who have received aid, $60 \%$ are men and $40 \%$ are women. At $13.71 \%$ of the population studied, their partner controls their way of dressing, of which 37.5 are men and 62.5 are women.

To $32.41 \%$ of the studied population, their boyfriend or partner has imposed whom to talk to and who to stop talking to, while $77.38 \%$ have not been imposed on who to talk or who to stop talking to. Among the population who are forced to speak to, each gender is $50 \% .10 .44 \%$ of the surveyed population, their partner, controls the way they groom themselves, cut their hair, speak, smile, while this type of violence does not happen to the rest, of which $60 \%$ are men and the $40 \%$ are women.

$22.99 \%$ of the student population surveyed, stated that their partner or boyfriend, checks their personal belongings such as cell phone, WhatsApp, Facebook, Email, handbag or wallet. To $76.60 \%$, they affirm that it has not happened, of the total, $50 \%$ corresponds to each gender.The student population surveyed who answered that if they have been emotionally blackmailed, their partner threatening to leave home, take their own life, or that they will consume drugs, after a violent period, amounts to $8.3 \%$, while those who have not been blackmailed emotionally, it makes up $91.2 \%$. Of this total, $73.1 \%$ are women who receive blackmail, while men suffer it in $25.6 \%$

$6.1 \%$ of the surveyed population, who have tried to kill themselves after having a fight with their partner, while $93.1 \%$ have never tried to kill themselves. Of this population that has tried to kill themselves, $72.8 \%$ are women, while $25.9 \%$ are men $22.4 \%$ of the students surveyed, witnessed scenes of violence during their childhood, while $76.6 \%$ stated that they had not experienced or observed violence. Of this total, the gender that had the highest frequency of perceiving violence in childhood was women, in $74 \%$, men perceived it in $24 \%$.
$7 \%$ of students affirm that their partner's periods of violence are caused by the use of alcohol or drugs, while $93 \%$ say that it is not.

Regarding the question, which is the gender that exercises the most violence, we find that it is the Male gender. And the gender that suffers the most is the female gender.

The answer to the question about the type of violence that is exercised more frequently in dating relationships in the students of the UAMCEH UAT, $32.41 \%$, of the studied population, which they impose on whom to speak and to whom to stop speaking. Both genders have a $50 \%$ frequency in raping their partner.

The type of violence that men exert on their partner, with greater frequency is the demand to practice sexual relations, of the students who suffer this violence, $66.7 \%$, while women exert it in $33.3 \%$

The type of violence that women exert against men most frequently is about how to groom, dress, smile, of the total of students who suffer this type of violence, $60 \%$, women exert it on men, while the man exerts it on the woman, in $40 \%$.

\section{References}

Aguilar, L. (2010). Manual para la prevención de la violencia. Amor y violencia en el noviazgo. febrero 2020, de Instituto Estatal de las Mujeres Sitio web: http://cedoc.inmujeres.gob.mx/ftpg/Tabasco/tab meta13_6.pdf

Asensi, L. (2016). La prueba pericial psicológica en asunde violencia de género. Testimonio pericial en casos de violencia doméstica.. febrero 2020, de Revista Internauta de Práctica Jurídica Sitio web: https://www.researchgate.net/publication/28204 320_La_prueba_pericial_psicologica_en_asunt os_de_violencia_de_genero_Expert_testimony_ in_cases_of_domestic_violence

Beck, A. (2003). Prisioneros del odio: las bases de la ira, la hostilidad y la violencia. España: Paidos Ibérica. 
Bottinelli,M. (2001). Herederos y protagonistas de Relaciones violentas: El Desafío de Los Agentes Sociales:Una mirada entre DOS Siglos. España: Lumen Books.

Bowlby, J. (1982). Apego y pérdida: retrospectiva y prospectiva. American Journal of Orthopsychiatry, 52 (4), $\quad 664$ 678. https://doi.org/10.1111/j.19390025.1982.tb01456.x

Cárdenas M. (2020). Revisión Latinoamericana sobre la violencia en el noviazgo dentro del período de 2006 a 2017. septiembre 2020, de Universidad Cooperativa de Colombia Sitio web:

https://repository.ucc.edu.co/handle/20.500.124 94/16977

Carranza, R, Galicia,I. (2020). Violencia de pareja en estudiantes universitarios, Un estudio comparativo entre carreras y semestres.. Septiembre 2020, de Revista Interuniversitaria Sitio web: https://gredos.usal.es/handle/10366/140854

Castro, R Casique, I. (2010). Noviazgo y violencia en el noviazgo: definiciones, datos y controversias. marzo 2020, de UNAM CRIM Sitio web: https://www.uv.mx/cendhiu/files/2016/01/4LECTURA-VIOLENCIA-

Celis,A, Rojas,J.. (2015). Violencia en el noviazgo desde la perspectiva de varones adolescentes. febrero 2020, de Universidad de la Laguna, españa Sitio web: dialnet.unirioja.es

Corsi, J. (1994). Violencia familiar. Una mirada interdisciplinaria sobre un grave problema social. México: Paidós.

Macías, B. (2003). Diccionario de Ciencias de la Educación. México: Santillana.

Levi Straus, C. (1988). El pensamiento salvaje . México: Fondo de Cultura Económica.

Magdaleno, M, Morello,P\&Infante, F. (2003). Salud y Desarrollo de adolescentes y jóvenes en Latinoamérica y El Caribe: desafíos para la próxima década. Salud Pública en México, 45, 7.
Muñoz, N, Espinobarros, F, Romero,Ch \&Rojas, J. (2020). Sexismo, celos y aceptación de violencia en jóvenes universitarios mexicanos.. Septiembre 2020, de Khatarsis Sitio web: https://www.researchgate.net/publication/34152 5709_Sexismo_celos_y_aceptacion_de_violenc ia_en_jovenes_universitarios_mexicanos

Papalia, D, Wendkos, S \&Duskin, R.. (2010). Desarrollo Humano. México: Mc Graw Hill.

Póo, A, \& Vizcarra,M. (2008). Violencia de pareja en jóvenes Universitarios. Terapia Psicológica, 26, 7.

Soriano, A. (2011). La violencia en las relaciones en pareja en estudiantes universitarios. Propuestas educativas. Pedagogía Social, 18, 7.

Torres, M. (2004). Violencia contra las mujeres en contextos urbanos y rurales. México: El Colegio de México.

Valenzuela,A \&Vega,M. (2015). Violencia en el noviazgo en adolescentes. Un problema de Salud Pública. febrero 2020, de RevsalJal Sitio web:

https://www.medigraphic.com/pdfs/saljalisco/sj $-2015 /$ jj153g.pdf

Villora, B. (2019). Abuso on line en el noviazgo de estudiantes universitarios: análisi de su prevalencia, factores de riesgo y repercusiones sobre el bienestar.. septiembre 2020, de Universidad de Castillo La Mancha Sitio web: uidera.uclm.es/xmlui/bitstream/handle/10578/2 3161/TESIS\%20Víllora\%20Galindo.pdf?seque nce $=1 \&$ is Allowed $=y$

Whaley,J. (2008). Violencia Intrafamiliar: Causas biológicas, Psicológicas e interaccionales. México: Plaza y Valdés.

Wolf,D, Scott,K, Reitzel,D, Wekerle,C Graslet C \& Straatman,A.. (2001). Desarrollo y validación del inventario de conflictos en relaciones de citas de adolescentes.. Psychological Assessment. 